\title{
Students' Perceptions of Language Anxiety in Speaking Classes
}

\author{
Mustafa Naci KAYAOĞLU, Hasan SAĞLAMEL*
}

\begin{abstract}
A considerable number of foreign as well as second language learners suffer from language anxiety when they step into the language classroom. What makes language learning environments, particularly English language learning situations, anxiety provoking has been well-established in language anxiety literature and the learners' perception of language anxiety deserve a special mention as they are one of the parties directly involved in learning process. To this end, this study aims at exploring learners' perceptions of language anxiety in speaking classes at a north-eastern state university in Turkey. Through a purposive sampling procedure, 30 students from different proficiency levels were interviewed. Findings from the semi-structured interviews are discussed with reference to learners' perceptions of learning English. Possible sources and manifestations of language anxiety from the learners' perspectives are examined and their suggested ways to lower language anxiety are discussed.
\end{abstract}

Keywords: language anxiety, student perceptions, speaking.

\footnotetext{
${ }^{*}$ Karadeniz Technical University.
} 


\section{Introduction}

For the last few decades, the chance of encountering anxious or more fragile learners is not remote. While this might be the case for all courses, a special mention is required for language learning contexts as they have usually been subject to anxiety-provoking contexts (Kondo \& Ying-Ling, 2004; Price, 1991). Given that anxiety arousal is more likely in speaking situations (Hewitt \& Stephenson, 2012; Von Wörde, 1998), shedding light on such situations would not be poorly grounded.

Research into language anxiety has consistently shown that anxiety could have a detrimental effect on L2 performance (Aida, 1994; Elkhafaifi, 2005; Horwitz, Horwitz, \& Cope, 1986; Humphries, 2011; MacIntyre, 1999; MacIntyre \& Gardner, 1994; Liu \& Jackson, 2008). In line with this hindrance, learners are reported to demonstrate a worse performance than usual (Hewitt \& Stephenson, 2012). Although there are numerous studies conducted in this field, lending a sympathetic ear to learners' perspectives would be enriching as their reports could be a predictor of the reasons, effects and manifestations of anxiety arousal.

\section{Review of Literature}

Language teaching pedagogy after the second half of the twentieth century has witnessed considerable shifts. Young (1999) summarizes these shifts as transitions from body to mind and to emotions referring to behaviourism, cognitive science and affect respectively. For a long time, emotions did not receive the due respect they deserve as they were treated as "subjective states of consciousness" (p. 18). After the recognition of language anxiety as a separate construct (Horwitz et al., 1986), researchers have begun to have a clearer view of the definition, reasons and effects of it.

\section{Conceptualization}

Several attempts to categorize and define language anxiety have been made. As for the categorization, an early attempt that calls for the recognition of intricate hierarchy of learner variables prior to measurement of anxiety was made by Scovel (1978), who was critical of the existing measurements. The gap Scovel draws attention to seems to be filled partly by Horwitz et al., (1986), who outlined a framework grouping foreign language anxiety under three components, namely communication apprehension, fear of negative evaluation and test anxiety.

Language anxiety or foreign language anxiety more specifically, is usually associated with situational anxiety since it is a particular language learning situation that triggers a learner to grow anxious. Young (1992) stresses the language learning contexts as the provoking factor for language anxiety and defines language anxiety as a construct peculiar to language learning situations while MacIntyre (1999) describe language anxiety as the "worry and negative emotional reaction aroused when learning or using a second language (p. 27). 


\section{Reasons for foreign language anxiety}

Daly (1991) focuses much on communication apprehension and cites genetic disposition; early reinforcements and punishments; early communication skills; and exposure to appropriate model of communication as the possible factors for language anxiety. Participants in Von Wörde's study (1998) report that non-comprehension, the pace and the risk of being singled out in speaking activities, the limited time devoted to pedagogical and instructional practices, the risk of being humiliated through error correction and the presence of native speakers could make them more anxious than usual. Gregersen and Horwitz (2002) suggest that perfectionism might impede high anxious learners' performance and some recommendations are offered to cope with perfectionist tendencies.

Woodrow (2006) draws a distinction between in-class and out-of-class anxiety and finds that communication with teachers and performing in front of a class are the major contributors to language anxiety in speaking classes. Specifically, giving oral presentations, role-play in front of class, contribution to formal discussions, answering teacher questions, informally speaking teachers were reported as major reasons for learners' in-class anxiety.

Moreover, Tanveer's 2007 study reveals that it is the intrinsic motivators, the learner's self in particular, that usually result in anxiety-breeding situations. Accordingly, learners' beliefs, perceptions and poor command of language could lead to a higher level of anxiety. Furthermore, some other extrinsic factors such as social and cultural environments could be the reasons for anxiety-provoking situations.

\section{Effects of foreign language anxiety}

MacIntyre (1999) examined the effects of language anxiety under four categories: academic effects, cognitive effects, social effects and personal effects. As for the academic effects, the literature on language anxiety has shown conflicting results regarding its impact. A great deal of research undertaken points to the debilitating effect of language anxiety (see Horwitz et al., 1986; Price, 1991) whereas its facilitating role is mentioned in several studies (Chastain, 1975; Ehrman \& Oxford, 1995).

Another possible impact of language anxiety could be cognitive factors. One example comes from Tobias model (see MacIntyre, 1999) in which there are three phases when processing input. These processes are input processing and output respectively. At the input stage some information is filtered through a kind of mechanism. In accordance with this model, the input which is hindered at one stage cannot move into another. Thus, a learner who gets anxious because the input received is fast may not be able to process the information at an expected speed.

Third, social effects of language anxiety could be noted when a social context triggers language anxiety. For instance, a classroom where there is a stiff competition, where some 
students are looking forward to finding others' mistakes to laugh at or where relations among the learner groups are sour are vulnerable to anxiety arousal. When in a competition, learners constantly compare themselves with the ones superior to them, thus losing their enthusiasm or sometimes giving up the task or avoiding the task. Krashen (1982) suggests that individuals' low self esteem might play a negative role in her/his language anxiety. How one perceives his/her self image has to do with the language anxiety s/he experiences. Moreover, learners' achievement could also be the predictor of their language anxiety level. For example, learners who feel that they take a back seat are prone to get anxious. Learners who consider themselves inferior to other learners with respect to their performance do not have a high opinion of themselves and this perception might trigger their language anxiety. These arguments seem to support Hembree (1988) and Price (1991), who argued that learners whose perceived proficiency is lower than that of others are more likely to experience language anxiety-arousal.

For personal effects, we can consider the reactions of individuals who experience these effects. An example from a learner's account in Prince's study would portray a vivid picture. The author studied the foreign language anxiety growing out of her own experiences in her own classrooms and she gathered some qualitative data from anxious students and one is depicted below:

I cancelled everything I was supposed to do because I could not sit through anything, knowing I had to study French. .... we tried to study. We were hysterical! ... I remember thinking on the way, I just can't do this. I'm going to have to drop this course." Another student reveals his/her experiences as follows: "French classes were very, very stressful for me, because I didn't speak well... Everything came out in a Texas accent, which was horrible; because the professors would stop me and made me go over and over it and I still couldn't get it right. The more they made me do it, the more frightened I became! (p. 105)

\section{Coping with anxiety}

The documented literature offers a wide range of ways to cope with anxiety. However, methods, techniques, activities or tricks with reference to the speaking skills will be chosen for the sake of relevance.

Teaching methodologies such the Community Language Learning, the Suggestopedia and Natural Approach took the responsibility of creating a comfortable atmosphere by ameliorating the performance of learners (Wilson, 2006). One example, to this end, comes from Ariza's 2002 study. The author who worked with four English speaking Puerto Ricans concluded that Community Language Learning would be a teaching implication to alleviate the anxiety of Spanish learners. 
A considerable number of studies suggest ways to cope with language anxiety. Tanveer (2007) offered friendly classroom environments, drama-like activities, avoidance of idealized forms of pronunciation and homogenous classes as less anxiety provoking whereas participants in Price's (1999) study point to the familiarity with other students, smaller classroom size, early start of language teaching, positive reinforcement, friendly role of the instructor as less stressful situations. Aydın and Zengin (2008) enumerated two major ways to curb language anxiety. One way is to teach students the strategies to cope with it and the second one is to provide a less stressful atmosphere for students. Köse (2005) tried dialogue journals as a possible way. However, his study indicated that using dialogue journals on the way to lower anxiety does not contribute to the alleviation of language anxiety. In her 2011 study, Humphries found that learners could help each other struggle with the anxiety without teacher assistance outside the classroom settings. Forming friendship has been found to have an alleviating role as learners are assured confidence when they establish a friendship with others.

\section{Methodology}

This study makes use of qualitative information to explore students' perceptions of language anxiety. Semi-structured interviews were used to discover students' reported reasons, manifestations and coping strategies of language anxiety. To this end, the following research questions are examined in this study.

1. What are the perceptions of students about language anxiety in speaking classes?

This question was attempted to explore through the following minor questions:

1. What are the students' perceived reasons for language anxiety?

2. How does language anxiety affect the students?

3. How do the students manifest their language anxiety?

4. How do the students cope with language anxiety?

\section{Interview}

Semi-structured interviews were used to elicit students' perceptions of language anxiety in speaking classes. Therefore, the study offers diverse range of the participants' experiences. The rationale for these interviews as a data gathering tool is that researchers can capture data that is not directly observable (Tanveer, 2007, p. 35). Dowsett presents some further advantages of interviews as follows: "flexibility" for researchers, "control and power" for interviewees and "access to other peoples' lives" (cited in Nunan, 1992, p. 150). Some other basic advantages of interview use were highlighted as to "select, reconstruct, and reflect" (Ohata, 2005, pp. 140-141) upon the participants' experience. 
The questions used during the interview on the students' perceptions of anxiety in the study were taken from Tanveer's (2007) study. The interviews took about 8-15 minutes and they were conducted in learners' mother tongue, Turkish, to facilitate communication and to promote richness of response and access to data in a less threatening medium. Some questions were reworded when interviewees did not understand the questions exactly.

\section{Setting}

The study was undertaken in the Department of Basic English, School of Foreign Languages, at a state university in north eastern Turkey. Each year, more than 2000 students from 21 different departments enrol in a mandatory preparatory program. At the dawn of each semester, there is a proficiency and placement test. According to the results of that examination, enrolling students either pass the proficiency test and continue in their own department or are placed as beginners, pre-intermediates and intermediates in the preparatory school. The researcher's own office was chosen to provide a quiet and peaceful atmosphere where there is no outside intervention. All interviews were recorded. Since they took a long time, relying on recall was not preferred. The recorder was regularly checked during the interviews because it is a battery-operated machine that could create some problems.

\section{Participants}

The participants for the study consist of 30 students. All participants in the study were native speakers of Turkish and they were briefly informed about the problem of language anxiety before taking the interview. The students were asked to reveal their feelings and perceptions of language anxiety. Their reports reveal that they study in different departments and were placed at different levels and each participant took speaking courses at least for 3 months. Due to confidentiality considerations, the participants were assigned pseudo-names such as \#3, \#16. Number \#14 and \#19 were omitted as there were leading questions and \#31 and \#32 were added instead.

\section{Sampling}

A purposive sampling procedure was followed for the students. The attendance list of the school was taken from the school administration and 30 students from different levels and different age levels (graduate and postgraduate) were chosen. The semi-structured interviews were audio taped and some were transcribed verbatim by the researcher to get familiarity. The others were coded when listening. Since it was a semi-structured interview some pre-specified points were highlighted and then analyzed. This made the work less time-consuming and less laborious because totally there were 30 interviews to work on. Content analysis was used to evaluate and interpret the data gathered. 


\section{Findings and Discussions}

The first item which was asked in the interview was: "How long have you been learning English and how do you feel about your experience of learning English?" Students' answers for this question varied greatly. Some of the students said that they had been learning English since high school, some since secondary school and some stated they had been learning it since high school. 7 students claimed that they had been learning English for 4 months which corresponded to the beginning of the semester at the School of Basic English. When asked if they had learned English prior to that period, all the seven students asserted that the attempts to learn English in primary and secondary schools were not fruitful. Therefore, some students considered only the learning experience in the school of Foreign Languages as it was their first serious endeavour to learn English. Here, serious and fruitful endeavour should be stressed because students usually ignored the time they spent studying English at primary school. Most of the respondents started with "in a genuine sense" implying that their efforts in primary and secondary school was not fruitful. Those who had attended a preparatory class usually underlined the school they studied. Such responses are a clear indication of the evaluation that has been underlined: "serious and fruitful endeavour". An interesting answer to this question appeared from the respondent \#31: "I have been learning English since the last holiday when I had a chance to talk to tourists". The respondent prefers to answer his learning experience in an informal setting in order to omit varying interpretations. It was found that most of the students (70\%) stated they started learning English in primary school while the others stated they started in high school.

Learning English has anxious connotations for a considerable number of the students. The adjectives in the right column represent these anxious connotations. Moreover, it would be convenient to state that a considerable number of the respondents answered this question referring to if clauses: "If you study really hard, it is a pleasant experience", "It is only welcoming if you have a good background". It is important to point that some learners suggested the role of the teachers when answering this question. "I really want to learn it, but I think it somehow depends on the teacher". $25 \%$ of the respondents wanted to share their past experiences when learning English and they stated that their earlier negative experiences had a negative impact on their perceptions of learning English. Moreover, it is important to refer to unwilling attitudes of the learners. 6 learners stated their unwillingness because the preparatory program was mandatory. The requirement to learn English in formal settings like

their schools was somehow intimidating because they did not feel comfortable with exams. However, there were voices that expressed happiness with this requirement, suggesting that English was a chance for them to catch up with the rising demands of the day. Job opportunities, academic studies and commonplace use of English in technology were some motives that drew them to comply with this necessity. Here are some answers from learners: 
a) pleasant, b) stressful, c) positive but anxiety-provoking, d) only necessary, e) enjoyable, f) good and difficult, g) boring and negative, h) I didn't use to like it, but now it is enjoyable, i) positive but somehow challenging, $\mathrm{j}$ ) difficult but enjoyable pleasant if you like the teacher.

\section{Possible Sources of Anxiety Reported by the Students}

Respondents' answers to the question "What disturbs students most about learning and speaking English and why?" were coded and a couple of themes were developed in the light of their answers (See Table 1). These are (1) linguistic difficulties: lack of sufficient vocabulary, a poor command of grammar rules and pronunciation difficulties (2) cognitive challenges: fear of failure (failure in communication, failing in exams, making mistakes, failing in front of others), lack of self-esteem, (3) lack of information in the L1, (4) the role of the teachers, and (5) competitiveness. The findings in this study reveal that linguistic difficulties come to the fore as vocabulary; grammar and pronunciation were cited by many of the respondents.

Table 1

Possible Causes of Language Anxiety in Speaking Classes According to Students

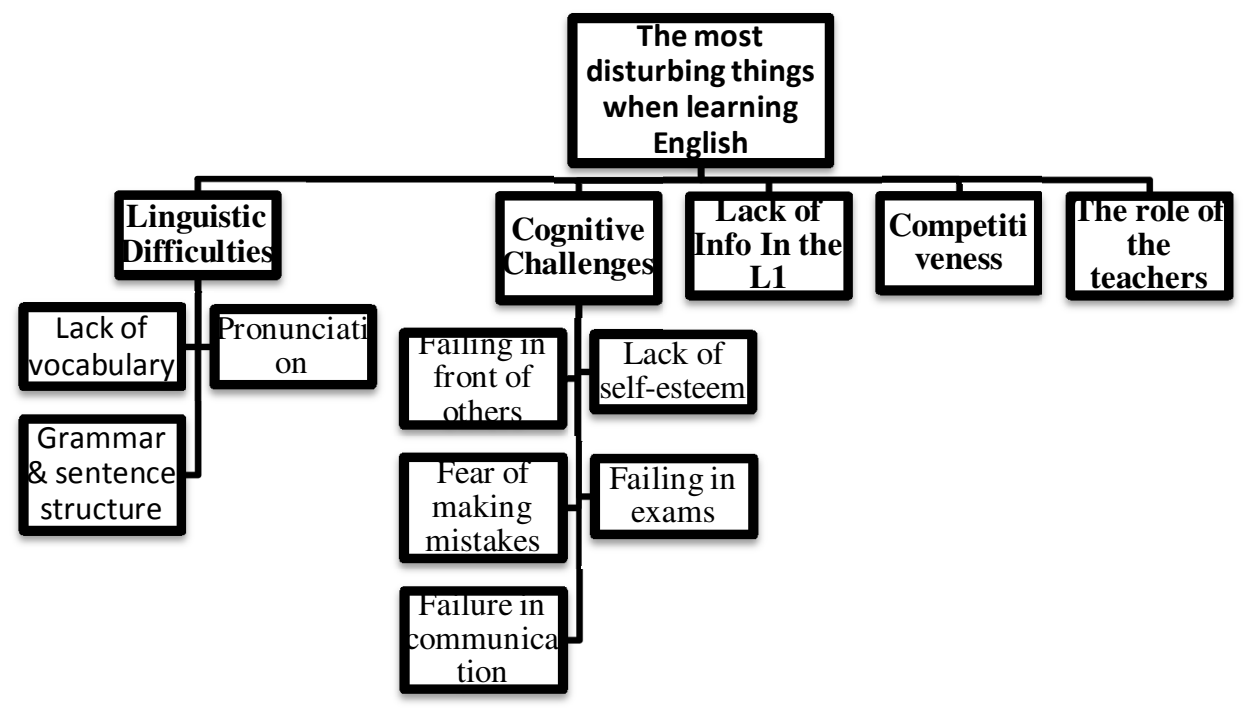

Linguistic Difficulties. It is no exaggeration that many learners experience a lot of difficulties when they are studying a second or foreign language. The difficulties they experience could develop into language anxiety:

At the earliest stages of language learning, a student will encounter many difficulties in learning, comprehension grammar and other areas. If that student becomes anxious about these experiences, if s/he feels uncomfortable making mistakes, then state anxiety occurs. 
After experiencing repeated occurrences of state anxiety, the student comes to associate anxiety arousal with the second language. (McIntyre, 1999, p. 31)

According to the findings obtained from the study, linguistic difficulties occupy a substantial place in the reasons for language anxiety. Of these linguistic difficulties, vocabulary was reported to have a remarkable share. Most of the participants revealed that it was vocabulary that made a difference when speaking because lack of sufficient vocabulary reported to be a great trap on the way to achieve a fluent speech. 11 of the respondents complained about insufficiency of word power. One of the students (\#16) indicated that not remembering the right word put him in a terrible situation. He struggled to remember the right word and spent a lot of time to do it. Some other respondents (\#1, \#5, \#9, and \#23) said that they had problems remembering the words. Therefore, the problem with vocabulary is twofold: insufficiency of enough words and retrieval of the vocabulary. It follows from this that strict obsession with a particular word could pose a challenge for students when they are making sentences. McIntyre and Gardner's (1994) experimental study of the effects of induced anxiety on vocabulary learning tasks could be referred to in support of these findings. They put an anxiety provoking object -camera- and indicated that the group exposed to camera experienced more vocabulary deficits than their counterparts.

Secondly, grammar is another linguistic difficulty reported by the respondents. Some students (\#8, \#13, \#24, \#25, and \#31) revealed that lack of grammatical knowledge and practice made them markedly uncomfortable when speaking English. To illustrate, one of the respondents (\#8) indicated that she had to use gap fillers such as "hmm", "errr" to gain some time to think about the correct usage and compensate for his poor grammar.

Pronunciation is another theme broken down from the content analysis. Some students (\#11, \#29, and \#30) stated the perception of their poor pronunciation disturbed them most when speaking. It is partly due to the possible absurd pronunciation mistakes that may occur when learners are talking. Here, an account of a learner (\#30) who made a pronunciation mistake provides a valuable example:

When I was talking in one of speaking classes at the beginning of the semester, I mispronounced the -ed form of a verb. The class burst into laughter when I made that mistake. I hadn't known the correct pronunciation until then. I was glad to learn the correct form, but unhappy with my friends' overreaction.

There are two difficulties with pronunciation tasks: at comprehension stage and at production stage. One learner (\#30) implied that his/her pronunciation difficulty lied in production stage, "If I cannot express myself clearly, then I grow anxious. I do not know the correct pronunciation of some even simple words and it makes me sick." However, some complaints referred to the comprehension stage as well: "If I cannot understand what the teacher is talking about it makes me feel nervous (\#22)". A lot of students made their 
complaints for comprehension level especially about the fast pace of the speakers (it might be their teachers, or the people from course book materials).

Cognitive Challenges. In the light of the responses, cognitive challenges are analyzed into five categories. These are: failing in front of others, failing in exams, failure in communication, fear of making mistakes and lack of self-esteem. Here, failing in front of others, failing in exams, failure in communication, fear of making mistakes can be grouped as fear of failure.

Firstly, students revealed that they are subject to failure especially in front of their friends. This failure usually occurs when students happen to make a presentation. A student provides evidence for his avoidance: "When I am nervous, I usually go red. For instance, I didn't want to participate in the karaoke and I told it to my teacher and he quite understood and I got the permission to change my task (\#9)". Daly (1991) concludes a chain of reasoning why the people who fail in front of others, or to put it differently, who suffer from stage fright. He argues that being self-focused might result in a lower concentration on the audience and the surrounding, which is replaced by a reduction in speech performance.

Secondly, fear of exams creates an intimidating atmosphere for students. "Exams make me so worried that I cannot realize my full potential because of them." said one of the respondents (\#27). Another learner (\#2) suggested her hopelessness considering a possible bad result, "I get overly anxious for exams and the question "what if I fail?" always prevails".

The fear of exams may trigger some other negative outcomes. Horwitz et al. (1986) describe how exams impede learners' performance as follows: "Test-anxious students often put unrealistic demands on themselves and feel that anything less than a perfect test is failure" (p. 128). This situation is reflected by a respondent (\#12): "Failing in the preparatory program will lead to family pressure and it will impose economic burden for us".

Moreover, failure in communication has been reported to be anxiety-breeding by the respondents. "I find it disturbing if I cannot express my opinions," said one of the respondents (\#4). Most of the students believe that language is for communication. Falling short of this aim creates unease because in such a situation respondents come to believe that their attempts are in vain. At this point, it should be noted that escalation of these communication breakdowns is somehow seeded into peoples' personality and might lead to a substantial decrease in motivation. However, the erroneous assumption here is that some people find communication apprehension as the single source of failure (Daly, 1991), thereby neglecting the other possible sources.

One of the most important issues to be handled here could be the fear of making mistakes. In daily life, we are inundated with a wealth of decision-making situations. Some of these decisions coincide with the expected targets and lead to success, but some might, though 
not in purpose, deviate from the expected route leading to mistakes. Being judged, rejected and humiliated are some key terms associated with mistakes. A considerable number of learners (11) stated that they were afraid of mistakes while some believed that it was worth experimenting with mistakes as they were opportunities for learning. "In fact, I am not a person who is afraid of mistakes, but in lessons mistakes mean fewer grades," indicated one learner (\#9) while another one (\#13) stated that a speech full of mistakes might lead to communication failure. Another learner (\#5) pointed to the unfavourable outcomes of making mistakes saying, "I think I'll appear foolish when I make mistakes." Appearing foolish, being humiliated or ridiculed have been noted as the common hesitations of the learners who are afraid of mistakes. However, when students were asked if they had had experienced such a thing before, only few (2) agreed. Surprisingly enough, those few students pointed that it didn't mean that those who laughed at them were ill-willed and sometimes they also laughed at the other person who made a silly mistake.

The role of the teachers. The growing emphasis on student autonomy has shifted the centre of gravity. What was teacher fronted once has become student-centred now. This transformation is not fully complete and in some countries it is quite burdensome. Before referring to students' perceptions of the role of the teachers, it is better to speculate the role of teachers in general. Many people attach a prominent role to teachers and hold this equation: "If you like the teacher, you will like the lesson". Failing to notice that the teacher is only a variable in learning process, some go far beyond this suggested role and say it is the teacher who has got the upper hand. In short, teachers could sometimes be considered as the key determinant of success or failure.

When it comes to the role of the teacher with regard to his/her treatment of language anxiety in classroom the abovementioned role does not seem to change for some learners. For a question intended to find out how learners view learning English, a respondent (\#28) stated "it depends on the teacher". According to the respondents, this role for teachers could be positive and negative. Some students reported that the teacher acts as a catalyst: "If the teachers didn't make it difficult, I wouldn't learn it (\#2)" and another (\#28) revealed that teachers should rein in the classroom: "Teachers should not let students feel free. Because ... in that case nobody will take turns; teachers should solicit turns otherwise not all the students participate willingly (\#28)”. Moreover, teachers' gentle attitude in attending mistakes, creation of a supportive environment, assignment of tasks beforehand and encouragement of group work have been cited less-anxiety breeding by respondents.

Some students levelled their criticism towards teachers. Here are some complaints about teachers: "Sometimes teachers keep a strict stance, thereby killing our passion (\#25)", "Teachers' attitude sometimes creates anxiety (\#24)", "Talking to teachers makes me unease (\#23)". When we go further to find out possible reasons, there are some surprising things. 
Teachers' delivery of turns might create a problem for learners. Sometimes teachers solicit turns directly and learners are caught unprepared. This situation makes the learners feel some discomfort. Sometimes teachers' commitment to speaking and pronunciation could be anxiety-inducing: "We hear four voices and these voices are different from each other. Thus, we cannot choose the correct pronunciation (\#24).

The significant role of teachers described above confirms early research on language anxiety. In a study aiming to discover the reasons for language anxiety, Williams and Andrade (2008) found that teachers shoulder a great responsibility, accounting for $50,61 \%$ of given variables, in causing anxiety for learners.

Competitiveness. Students at times feel that the model or the desired goal for them is not to have a passing grade, a good command of the lesson or develop an understanding of issues in their field; rather it is to be as good as their friends. Sometimes this becomes a driving force for them, but sometimes falling behind peers could let learners harbour feelings of unease. This is the case for a small percentage of students. An example comes from a female learner (\#24) who said, "I cannot produce sentences as well as my peers." As indicated here, the model is the peer and falling behind the mainstream population creates anxiety. Another student (\#17) gave a piece of advice to others when they are anxious: "Just look at those who are inferior. You will feel happy then." It is true that in a stiff competition everybody tries to become better than their counterparts. However, constant targeting of "betterment" may put strain on learners' shoulder. Therefore, a competitive atmosphere could sometimes not work in EFL settings.

Lack of information in the native language. An important disturbing point for the respondents is the lack of information about a subject. Sometimes being armed with sound necessary linguistic information does not guarantee a successful communication. One also needs some information about a topic that s/he is talking about. Unfortunately, some students claim that they have no opinion about a particular issue. A learner (\#20) expressed, "I don't have a good background to establish a good discussion." This negative self-perception or selfassessment creates a mental obstacle to go into the task or to participate willingly.

Comparison of Courses with Regard to Anxiety. The students were asked to compare the courses they had studied such as history, maths, etc. with English to explore their orientation to anxiety breeding courses. 28 students out of 30 (\%93.75) stated that English lessons took the first seat in terms of their anxiety-breeding nature. "In other courses, I don't get anxious," said several learners (\#1, \#5, \#6, \#7, \#10, \#27, and \#30). Some others gave an account of why they feel more anxious in English courses, "I believe all the courses are more or less the same, but in English classes, students are more disadvantageous because it is a new language (\#4)"; "Sometimes you may not know the answer in any course. However, the problem with English classes is that there are times when you cannot articulate your opinions 
even if you know the answer (\#11)." One of the students who did not rank English courses as the highest anxiety provoking (\#18) claimed that it is history in which she feels more discomfort while the other (\#24) suggested that he does not get much anxious in English courses since it is not his departmental course.

The findings here reveal that a great majority of students say it is English that is most provoking and this finding is consistent with early studies in the field. Sparks and Ganschow (1991) suggested that specific language-encoding difficulty in language courses could make it anxiety-breeding even if the students do well in other courses. Moreover, MacIntyre (1995) claimed that some strategies to cope with problems can be developed in L1, but not in L2.

\section{Manifestation of Language Anxiety}

Language anxiety could be manifested in a number of ways. For this study four themes were grouped and these themes are cognitive, physical, linguistic and behavioural changes. Table 2 gives some clues about each change.

Table: 2

Manifestation of Anxiety

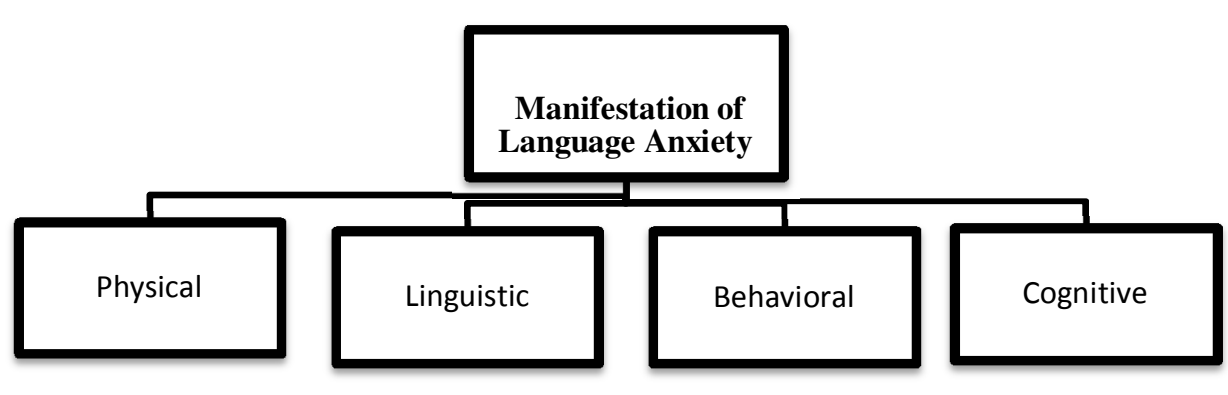

Physical and Physiological Manifestations. Some visible changes become apparent when learners get anxious. Here, it is referred as a "change" because learners do not feel what they normally do. In this line, most of the learners reported that they had experienced physical and physiological changes, rather than the others. Here are some accounts: "My hands shake (\#1)"; "I tremble (\#4)"; I have a stomach ache (\#10); "I go red. My heart beats faster (\#16); "I blush, begin sweating (\#20)." The respondents (\#22, \#23, \#24, \#28, \#29, \#30, \#31 and \#32) reported that they have experienced blushing and sweating when they feel anxious. Here an important example about this kind of manifestation could be given. One respondent (\#21) stated that constant exposure to anxiety might create some physical problems: "When I speak I grow anxious; I blush .... Everything goes upside down. I see the physical changes in my body, I lose my hair, I have some bruises." 
Cognitive Manifestations. Learners believe that some differences could occur when they feel anxious and these differences or changes could be at cognitive level. The word cognitive refers to one's thinking process; therefore, manifestations of this sort are not observable. Here are some accounts of respondents:

"I don't think I have great physical changes, but inside I feel very bad (\#2)",

"I tremble and panic; it appears to me that the teacher is insulting me. (\#4)",

"If I cannot find that specific word, all the parts go away. It is just like a puzzle (\#5)",

"I sometimes cannot even tell my name. The classrooms walls turn out to be dungeons and when you leave the room you feel better. Time does not run, everything turns upside down (\#12)".

As these accounts suggest, learners' thinking could be a determinant of their nervousness.

Linguistic manifestations. The representations of language anxiety could occur at linguistic level. Problems such as staggering voice, translation problems and feeling tonguetied and not being able to respond were highlighted about this point. "I get upset. I feel just like people who are deaf and dumb. (\#8)" suggested a learner. "My voice staggers and sometimes goes off, (\#12)" said another. Another learner suggested that he used translation to feel comfortable, but in the event of failure to translate, things could reportedly be troublesome.

Researcher: "What kind of difficulties do you experience when speaking English?"

(\#31): "I always think of the answers in my mother tongue first. But if I cannot translate them, everything goes off. Nothing comes to my mind then."

Behavioural Manifestations. Two respondents mentioned behavioural manifestations in their speech. One of them (\#13) said, "If I am stressed, this is reflected in my speech. My behaviours change, I am usually active, but when I am anxious I lose my spirit." Unlike the respondent \#13, respondent \#27 believed that change of behaviours in important settings would indicate one's weakness, "If I blush, for example, my interlocutor could get it as a weakness."

\section{Suggested Ways to Lower Language Anxiety}

So far a number of ways have been offered to lower anxiety. In this part, some concrete suggestions for creating a less stressful class have been made by the learners. Recorded data on alternative ways to lower anxiety was grouped into three categories: lowering teacher-induced anxiety, course-induced anxiety and learning context-induced language anxiety. 
Lowering teacher-induced anxiety. According to the respondents, a substantial number of students hold the idea that teachers could play a salient role. The respondents believe that teachers' treatment behaviour, attitude, turn-distribution, academic competence and evaluation of students' level are some issues that could help them feel less anxious.

The most rated thing in the interview was found to be teachers' evaluation of the students' level. The respondents told that teachers should be mindful of students' level. This is partly because some zero beginners and false beginners are sometimes placed in the same classroom and the teacher can regulate the flow of the lesson according to the false beginners. Thus, zero beginners in such a situation might be disadvantageous. One respondent (\#6) reported that the teacher should watch their level while another learner (\#8) wanted teachers to appeal to their level. "Our teacher shouldn't assume that this student should know this," asserted a respondent (\#5).

Turn-giving practices might matter. Several learners argued that some specific individuals should not be singled out in speaking courses. In cases where general soliciting does not work, the teacher should deliver the turns directly to create a sort of harmony in the classroom. This idea is reflected in the respondent \#22, "Assignments should be given beforehand and students should not be pushed to respond abruptly; but sometimes teachers should push the learners."

Third, the attitude of the teachers could be of some help to alleviate language anxiety. The respondents usually suggested that a friendly teacher who keeps a positive attitude is welcome. The teacher who makes the lesson more of a fun than a requirement is usually instrumental in lowering the language anxiety.

Fourth, teachers' academic competence has been noted as an important point to lower anxiety. Teachers' strict devotion to old-fashioned methods could be anxiety-inducing for learners. For instance, teachers' obsession with grammar rules has been reported to be anxiety-breeding. A significant point to be handled here is teachers' error treatment behaviour. The respondents usually demanded tolerance of mistakes.

In the light of learners' accounts, it is possible to say that level division of the students should be made more carefully so as not to make a few shine and let others take care of themselves. Addressing to a particular group might kill the willingness of others. The teacher should feel the pulse of the classroom when delivering turns and treating mistakes.

Lowering course-induced anxiety. The issue of language anxiety could be rooted to courses studied. Therefore, vocabulary development which has been noted as a crucial factor in causing anxiety should be considered essential in developing the syllabus for speaking courses. 
Moreover, some respondents (\#6 and \#11) complained about the time they started learning and speaking English. "I wish I had started earlier," said one respondent (\#6). After a certain period learners feel themselves in a disadvantaged position to learn and speak the language. This could be explained through Krashen's (1982) Monitor Hypothesis. Youngsters feel free to make mistakes and take risks whereas adults monitor their speech after a certain age.

Lowering learning context-induced anxiety. Students usually do not feel themselves free in a formal setting. Therefore, teaching atmosphere itself has been suggested as an anxiety-inducing factor for students. Creating less formal situations has been a goal to reach optimum ripeness. "If you make a mistake in a serious situation, things will be troubling," said one learner (\#9). Associating classroom setting with a formal setting could bring about some emotional detachment whereas a cooperative atmosphere could prove to be supportive for learners. Therefore, creating a friendly atmosphere to encourage cooperation rather than competition would be meaningful. As some learners suggest, "transforming test-based assessment to game-like activities (\#2, \#31,\#32)." would be a step that could be taken. This could be achieved through drama activities.

\section{Conclusion}

The possible reasons, effects, manifestations and ways to cope with language anxiety were investigated from the students' perspective through the interviews. It was found that linguistic difficulties (vocabulary, grammar and pronunciation), cognitive challenges (fear of failure in front of others, fear of exams, fear of failure in communication, lack of self-esteem, fear of making mistakes), the role of the teachers, competitiveness and lack of information were considered to be correlates of language anxiety. Lack of sufficient vocabulary and the role of the teachers were notably reported to be the possible reasons for language anxiety. From these accounts, it could be speculated that learners, except for their linguistic deficiencies, usually attribute their anxiety to external reasons. However, it is surprising to see that linguistic difficulties were not mentioned in their suggested ways to cope with language anxiety. Moreover, learners did not indicate themselves as the potential contributing factor of language anxiety, unlike the ones in Aydın's (1999) study. This takes us to conclude that learners want something from "outside" to let them curb their unease in language learning situations. To this end, the integration of linguistic and non-linguistic elements in coping strategies take us to consider anxiety beyond its competence-reduced form and interpret it in a more dynamic way.

Though a total elimination of language anxiety may not be a realistic aim, finding ways to enable learners to cope with the tension they are likely to face in foreign or second language learning situations remains salient. Since the findings in this study are based upon the learners' perspectives, further research on the correlates of language anxiety with 
reference to the gravity of anxiety arousal and specific avenues of coping could provide the basis for a more comprehensive picture, thereby limiting the classroom practices to immediate local needs.

\section{References}

Aida, Y. (1994). Examination of Horwitz, Horwitz, and Cope's construct of foreign language anxiety: The case of students of Japanese. Modern Language Journal, 78, 155-168.

Ariza, E. N. (2002). Resurrecting "old" language learning methods to reduce anxiety for new language learners: community language learning to the rescue. Bilingual Research Journal: The Journal of the National Association for Bilingual Education, 26(3), 717-728.

Aydin, B. (1999). A study of the sources of foreign language classroom anxiety in speaking and writing classes, (Unpublished doctoral dissertation). Anadolu University, Eskisehir.

Aydin, S. \& Zengin, B. (2008). Anxiety in foreign language learning: A review of literature. The Journal of Language and Linguistic Studies, 4 (1), 81 - 94.

Chastain, K. (1975). Affective and ability factors in second language acquisition. Language Learning, 25 (1), 153-161.

Daly, J. A. (1991). Understanding communication apprehension: An introduction for language educators. In E. K. Horwitz \& D. J. Young (Eds.), Language Anxiety: From theory and research to classroom implications (pp. 3-13). Englewood Cliffs, NJ: Prentice Hall.

Dowsett, G. (1986). Interaction in the semi-structured interview. In M. Emery (ed.), Qualitative Research. Canberra: Australian Association of Adult Education.

Ehrman, M. E. \& Oxford, R. L. (1995). Cognition plus: Correlates of language learning success. Modern Language Journal, 79(1), 67-89.

Elkhafaifi, H. (2005). Listening comprehension and anxiety in the Arabic language classroom. Modern Language Journal, 89(2), 206-220.

Gregersen, T. S., \& Horwitz, E. K. (2002). Language learning and perfectionism: Anxious and non-anxious language learners' reactions to their own oral performance. The Modern Language Journal, 86(4), 562-570.

Hembree, R. (1988). Correlates, causes, and treatment of test anxiety. Review of Educational Research, 58, 47-77.

Hewitt, E., \& Stephenson, J. (2012). Foreign language anxiety and oral exam performance: A replication of Phillips's MLJ Study. The Modern Language Journal, 96, 170-189.

Horwitz E. K., Horwitz. M., \& Cope J. (1986). Foreign language classroom anxiety. The Modern Language Journal, 70(2), 125-132. 
Humphries, R. (2011). Language anxiety in international students. Griffith Working Papers in Pragmatics and Intercultural Communication 4, 1/2 (2011), 65-77.

Kondo, D. S., \& Y. Ying-Ling, (2004). Strategies for coping with language anxiety: The case of students of English in Japan. ELT Journal, 58(3), 258 - 265.

Köse, E. (2005). Impact of dialogue journals on language anxiety and classroom affect, (Unpublished master's thesis). Ankara: Bilkent University

Krashen, S. D. (1982). Principles and practice in second language acquisition. Pergamon.

Liu, M., \& Jackson, J. (2008). An exploration of Chinese EFL learners' unwillingness to communicate and foreign language anxiety. Modern Language Journal, 92, 71-86.

Maclntyre, P. D. (1995). On seeing the forest and the trees: A rejoinder to Sparks and Ganschow. Modern Language Journal, 79, 245-248.

MacIntyre, P. D. (1999) Language anxiety: a review of the research for language teachers. In D. J. Young (Ed.) Affect in foreign language and second language learning: a practical guide to creating a low-anxiety classroom atmosphere. Boston: McGraw-Hill.

MacIntyre, P. D., \& Gardner, R. C. (1994). The subtle effects of language anxiety on cognitive processing in the second language. Language Learning, 44, 283-305. doi: 10.1111/j.1467-1770.1994.tb01103.x

Nunan, D. (1992). Research methods in language learning. Cambridge: Cambridge University Press.

Ohata, K. (2005). Language anxiety from the teacher's perspective: interviews with seven experienced ESL/EFL teachers. Journal of Language and Learning, 3(1), 133-155.

Oxford, R.L. (1999). Anxiety and the language learner: new insights. In J.Arnold (Ed.). Affect in language learning. Cambridge: Cambridge University Press.

Price, M.L. (1991). The subjective experience of foreign language anxiety: Interviews with highly anxious students. In Elaine H. and Dolly Y. (eds.). Language Anxiety: From theory and research to classroom implications. Englewood Cliffs, NJ: Prentice Hall.

Richards, J.C. \& Rodgers, T. (2002). Approaches and methods in language teaching (2nd ed.). New York: CUP.

Sağlamel, H. (2009) An experimental study on the role of creative drama in alleviating language anxiety in speaking classes with reference to teachers' and learners' perceptions of language anxiety, (Unpublished master's thesis). Karadeniz Technical University, Turkey.

Scovel, T. (1978). The effect of affect on foreign language learning: A review of the anxiety research. Language Learning, 28, 129-42

Sparks, R. L., \& Ganschow, L. (1991). Foreign language learning difficulties: Affective or native language aptitude differences? Modern Language Journal, 7, 3-16. 
Spielmann, G., \& Radnofsky, M. L. (2001). Learning language under tension: New directions from a qualitative study. Modern Language Journal, 85(2), 259-278.

Tanveer, M. (2007). Investigation of the factors that cause language anxiety for ESLEFL learners in learning speaking skills and the influence it casts on communication in the target language (Master's thesis). University of Glasgow, England. Retrieved from http://www.asian-efl-journal.com/thesis_M_Tanveer.pdf

Von Wörde, R. (1998). An investigation of students' perspectives on foreign language anxiety. Unpublished Ph. D. Dissertation, George Mason University, Washington D.C.

Williams, K. E., \& Andrade, M. R. (2008). Foreign language learning anxiety in Japanese EFL university classes: Causes, coping, and locus of control. Foreign Language Teaching, 5(2), 181-191.

Wilson, J. T. S. (2006). Anxiety in learning English as a foreign language: Its associations with students variables, with overall proficiency, and with performance in an oral test. Unpublished Ph. D. Dissertation, University of Granada, Spain.

Woodrow, L. (2006). Anxiety and speaking English as a second language. RELC, 37(3), 308328.

Young, D. J. (1992). Language anxiety from the foreign language specialist's perspective: Interviews with Krashen, Omaggio Hadley, Terrell, and Rardin. Foreign Language Annals, 25(2), 157-172.

Young, D. J. (1999). A Perspective on foreign language learning: From body to mind to emotions. In Young, D. J. (Ed.), Affect in foreign language and second language learning, (pp.13-23). Boston: McGraw-Hill. 